\title{
Floristic diversity of steppe vegetation in the region of Djelfa, North-West Algeria
}

\author{
Noureddine Habib ${ }^{1,2}$, Zineb Regagba ${ }^{1,2}$, Mohamed Djamel Miara',3, Mohammed Ait Hammou ${ }^{1,3}$, Julie \\ Snorek ${ }^{4}$ \\ ${ }^{1}$ Faculty of Nature and the Life sciences, Ibn Khaldoun University, Tiaret, BP. 78 Zaâroura, Tiaret, 14000 Algeria. \\ ${ }^{2}$ Laboratory of Geomatic and Sustainable development, LGeo2D, University of Ibn Khaldoun, Tiaret, Algeria. \\ ${ }^{3}$ Labortaory of Agrobiotechnology and Nutrition in arid and semi-arid areas, University of Ibn Khaldoun, Tiaret, Algeria. \\ ${ }^{4}$ Department of Environmental Studies, Dartmouth College, Hanover, NH, USA.
}

\author{
Correspondencia \\ Mohamed Djamel Miara \\ e-mail: miara14130@yahoo.fr \\ Recibido: 24 febrero 2020 \\ Aceptado: 24 abril 2020 \\ Publicado on-line: 15 mayo 2020 \\ Editado por: Marta Recio Criado
}

\begin{abstract}
This study is a floristic investigation of the steppe region of Djelfa located in northern Algeria, with the aim of characterizing and analysing the wild flora of this region. Four stations were chosen according to a stratified sampling method and phyto-ecological surveys were carried out in 32 plots of $100 \mathrm{~m}^{2}$ each. This allowed us to identify 127 taxa of plants belonging to 33 families dominated by Asteraceae $(29 \%)$ and Poaceae (12\%). The analysis of biological types has shown the dominance of annual Therophytes (56\%) in this flora, which indicates the presence of the phenomenon of Therophytization in these regions. This phenomenon was also measured by calculating the perturbation index. The analysis of chorological types has shown the dominance of the Mediterranean element $(48 \%)$, with an interesting number of endemic taxa. However, all the endemic taxa cited in the literature for this region have not been found, which reinforces our fears about the state of conservation of these taxa of biological and heritage value.
\end{abstract}

Key words: Chorology, Djelfa, Endemic Flora, Steppe, Stratified method

\section{Résumé}

Analyse floristique de la végétation steppique dans la région de Djelfa, NordOuest algérien

\begin{abstract}
Cette étude est une investigation floristique de la région steppique de Djelfa située au nord de l'Algérie, et cela dans le but de caractériser et d'analyser la flore sauvage de cette région. 4 stations ont été choisies selon une méthode d'échantillonnage stratifié et des relevés phytoécologiques ont été réalisés sur 32 parcelles de $100 \mathrm{~m}^{2}$. Cela nous a permis d'identifier 127 taxons de plantes appartenant à 33 familles dominées par les Asteraceae (29\%) et les Poaceae $(12 \%)$. L'analyse des types biologiques a montré la dominance des Thérophytes annuels $(56 \%)$ dans cette flore, ce qui indique la présence du phénomène de Thérophytisation dans ces régions. Ce phénomène a également été mesuré en calculant l'indice de perturbation. L'analyse des types chorologiques a montré la dominance de l'élément méditerranéen (48\%), avec un nombre intéressant de taxons endémiques. Cependant, tous les taxons endémiques cités dans la littérature pour cette région n'ont pas été retrouvés, ce qui renforce nos inquiétudes quant au statut de conservation de ces taxons de valeur biologique et patrimoniale.
\end{abstract}

Mots clés : Chorologie, Djelfa, Flore endémique, Steppe, Méthode stratifiée

\section{Introduction}

The Mediterranean region is characterized by an exceptional biological diversity as well as considerable biological richness estimated at 25,000 species of vascular plants, which corresponds to $9.2 \%$ of the total diversity of species in a territory representing only $1.5 \%$ of the terrestrial surface (Médail \& Quézel, 1997; Myers, 1988, 1990;
Mittermeier et al., 2004). Algeria, due to its geographical position, presents a great diversity of habitats occupied by an important floristic richness (Médail \& Quézel, 1997; Véla \& Benhouhou, 2007 in Miara et al., 2018a).

According to Quézel \& Santa (1962-63 in Véla \& Benhouhou, 2007), the Algerian flora comprises 
3,139 species consisting of 3,744 taxa including 464 endemic and 1,818 more or less rare species. This inventory is now evaluated at 4,449 taxa including 3,951 native taxa and 498 introduced to Algeria (Dobignard \& Chatelain, 2010-13). The flora of this country is mainly dominated by 3 botanical families with more than 150 species each: Asteraceae, Poaceae and Brassicaceae (433, 289 and 171 species, respectively), while 7 genera present between 30 and 58 species: Helianthemum, Linaria, Centaurea, Ononis, Trifolium, Astragalus, Silene (Abdelguerfi \& Ramdane, 2003).

The Algerian steppes constitute a geographical unit whose limits are defined by a bioclimatic criterion. With an estimated area of about 20 million hectares, the Algerian steppes are located between the 400$\mathrm{mm}$ rainfall isohyet to the North and $100 \mathrm{~mm}$-rainfall isohyet to the South, forming a $1000-\mathrm{km}$-long ribbon over a width of $300 \mathrm{~km}$ in the west and in the center, reduced to less than $150 \mathrm{~km}$ in the East (Halem, 1997 in Miara et al., 2018b). According to Nedjraoui \& Bedrani (2008), the steppe regions constitute a buffer between coastal Algeria and Saharian Algeria, of which they limit the negative climatic influences on the former.

Several studies (Le Houerou, 1969; Djebaili, 1978; Aiduod, 1983) confirm that in the Algerian steppe, the reduction in floristic diversity is not only occurring as a result of climatic factors (dryness and heightened aridity), but it is also strongly impacted by anthropic factors (primarily fires and grazing), which are prompted by irrational land exploitation such as overgrazing and land clearing.

To this, the effect of the phenomenon of therophytization is also to be considered. According to Quézel \& Médail (2003). Therophytization can be defined as the generalized invasion by annual and often ruderal species, which are mainly disseminated by herds. According to Daget (1980), this is a characteristic of arid zones, expressed as a strategy of adaptation to unfavorable conditions and a form of resistance to harsh climatic conditions.

The region of Djelfa is located in the south of the Algerian Tell Atlas in contact with the Saharian Atlas.

This region is a typical example of the North African steppe which is highly threatened and weakened by ecological and anthropic factors including desertification (Nedjraoui \& Bedrani, 2008).

So, in order to contribute to better conservation of these very sensitive natural spaces, a deeper knowledge of the biodiversity of these areas is essential. Unfortunately, and despite several floristic studies published recently for the region of Djelfa (Korichi, 2016; Maamri, 2016; Rahmoune, 2018; Benalia et al., 2018; Bekai et al., 2019), the floristic knowledge on this area is still insufficient, while several endemic and rare taxa cited in this region since the colonial period there has not been observed, namely: Erodium hymenodes L'Her., Echium suffruticosum Baratte., Celsia battandieri Murb. Bellium rotundifolium (Desf.) DC., Atractylis polycephala Coss. and A. phaeolepis Pomel.
This research aims to highlight the floristic diversity of the wild steppe areas of the Djelfa region in the Northwest Algeria, by seeking the aforementioned taxa. Specifically, we will assess the floristic biodiversity of this region to analyze some aspects related to the local flora such as life traits (biological types) and chorology (chorological types).

\section{Materials and methods}

\section{Study area}

The province of Djelfa is located in the central part of Algeria beyond the southern boundary of the Tellian Atlas; our study area is located between $2^{\circ}$ and $5^{\circ}$ of longitude East and $33^{\circ}$ and $35^{\circ}$ of North latitude (Figure 1). Three quarters of the territory of the province of Djelfa is made up of steppe ecosystems. In addition, a significant forest heritage exists in this region and consists mainly of Aleppo pine $(215,182$ ha), representing only $6.67 \%$ of the total area of the province (Cherfaoui, 2017).

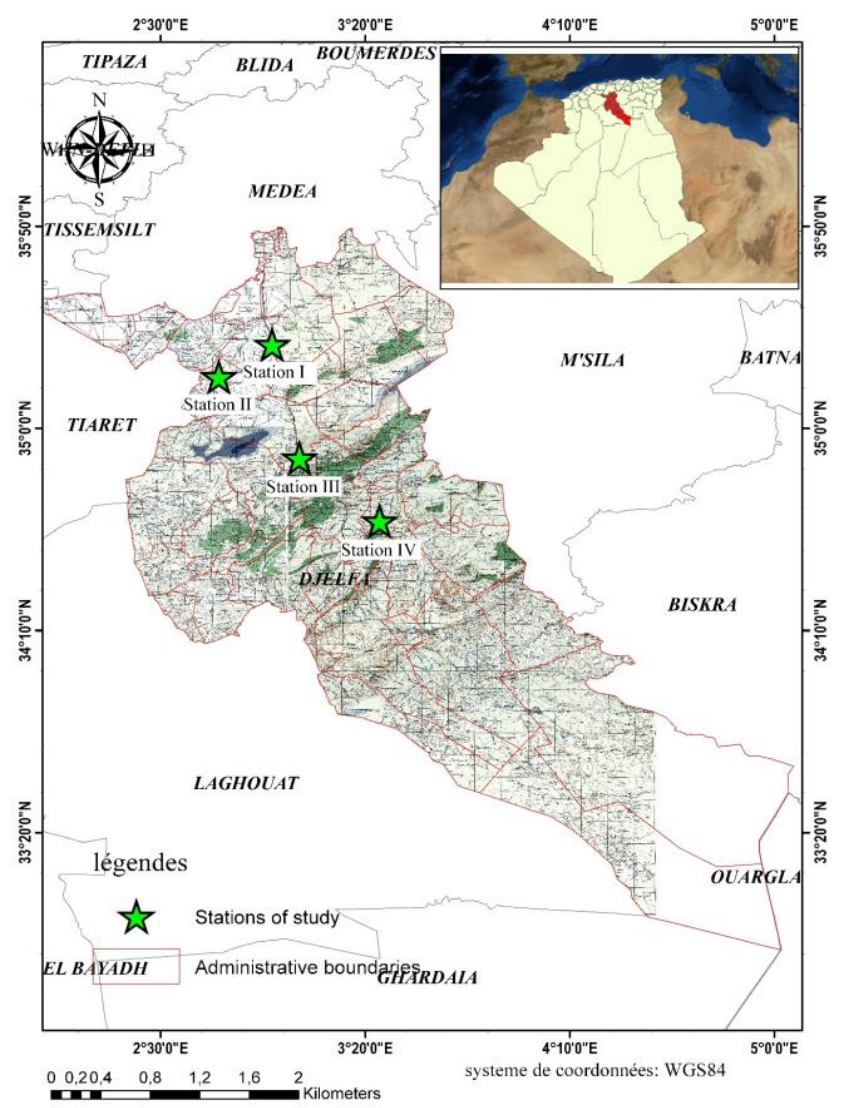

Figure 1. Geographical location of the study area.

Figure 1. Localisation géographique de la zone d'étude.

\section{Field sampling}

We carried out a total of 32 phytoecological surveys at 4 stations (Table 1) which were chosen according to a stratified sampling method (Gounot, 1969). 
The station $I$ is located in Ain Oussera at approximately $90 \mathrm{~km}$ northwest of the province of Djelfa. It is characterized by some diversified steppe formations with Stipa tenacissima L. and Artemisia herba-alba Asso.

The station // is located in Guernini at approximately $80 \mathrm{~km}$ northwest of the province of Djelfa. It contains some degraded rangelands with vegetation dominated by Stipa tenacissima L. and Lygeum spartum L.

The station III is located in Zaafrane, $60 \mathrm{~km}$ northwest of the province of Djelfa. It is characterized by sand dunes with vegetation dominated by Tamarix gallica L. In this area, there are also some artificial plantations of Atriplex canescens Sieb is located in the region of Ain Maabed at $30 \mathrm{~km}$ from the province of Djelfa.

The station $I V$ is located in the city of Moudjbara at approximately $18 \mathrm{~km}$ southeast of the province of Djelfa. It is characterized by pre-forest formations dominated by Pinus halepensis Mill., Stipa tenacissima L. and Artemisia herba-alba Asso.

\section{Data collection and plant identification}

The location of the 32 phytosociological surveys was chosen in a random way in zones that were clearly homogeneous and representative. Surveys were carried out according to the method of BraunBlanquet (1951). For each surveys, we noted the floristic, geographical and environmental data.

Table 1: GPS coordinates and altitudes of the 4 stations of Djelfa province.

Tableau 1: Coordonnées GPS et altitudes des 4 stations de la province de Djelfa.

\begin{tabular}{lccc}
\hline \multicolumn{1}{c}{ Stations } & Longitude & Latitude & Altitude \\
\hline Station I (Ain Ouessara) & 2,95 & 35,34 & 728 \\
Station II (Guernini) & 2,73 & 35,21 & 814 \\
Station III (Ain Maabed) & 3,06 & 34,89 & 881 \\
Station IV (Moudjbara) & 3,40 & 34,57 & 1320 \\
\hline
\end{tabular}

In each station, we took eight floristic samples from an area measuring $100 \mathrm{~m}^{2}$. According to Djebaili (1984), this surface is the minimum area required to be a representative sample of the characteristic flora of the Algerian steppe regions. These floristic surveys were carried out during the optimal periods (spring) of 2016 and 2017. The botanical identification of the collected taxa was made using the flora of Quézel \& Santa (1962-63) and that of Ozenda (1977). The species chorology was defined according to Dobignard \& Chatelain (2010-13). Chorological types have been grouped according to Benabadji et al. (2007) which comprises the following groupings: 1) Mediterranean species (West-Mediterranean, EastMediterranean, Ibero-Mauritanian, CenterMediterranean, Sub-Mediterranean), 2) Nordic species (European, Eurasians, Paleo-temperate, Boreals-circum and Paleo sub-tropical), 3) widely distributed species (Euro-Mediterranean, AtlanticMediterranean, Eurasian-Mediterranean, IranoTouranian, Cosmopolitan), 4) Saharan species and 5) endemic species. The nomenclature of the identified taxa was updated using the synonymic index of North Africa (Dobignard \& Chatelain, 2010-13). The specimens of plants harvested in the field were coded and deposited in the herbarium of the Botanical laboratory of the University of Tiaret, Algeria.

The perturbation index (PI) is used to quantify the therophytisation. It is calculated according to Loisel \& Gamila (1993) as the ratio of the sum of chamaephytes and therophytes on the full number of the species.

\section{Results and discussion}

\section{Floristic analyses}

In total, we recorded 127 taxa at the four sites (Table 2). This number seems very interesting compared to that obtained by some authors who worked in the same region including Zehraoui (2016) with 107 species, Korichi (2016) with 66 species, Maamri (2016) with 129 species, Rahmoune (2018) with 126 species, Benalia et al. (2018) with 84 species and Bekai et al. (2019) with 106 species.

Our taxa belong to 33 botanical families. The most represented families are: Asteraceae (37 taxa, 29\%), Poaceae (15 taxa, 12\%), Brassicaceae and Fabaceae with a total of 11 taxa (9\%) per family (fig.2). Other families like Amaranthaceae, Lamiaceae and Caryophyllaceae are moderately represented with 6,5 and 4 taxa respectively. The rest of the families are poorly represented and accounted less than 4 taxa. According to Ozenda (1977), Asteraceae, Poaceae and Brassicaceae characterize the arid and semi-arid areas in the Mediterranean regions.

In Algeria, some studies (Benabadji et al., 2007; Kazi-Tani et al., 2010) highlighted the dominance of Asteraceae, Poaceae and Fabaceae in the steppe regions. This was also reported in Morocco by Fennane et al. (2012).

In the region of Djelfa, the study of Djaballah \& Chehma (2008) about the floristic and nutritional characteristics of the steppe rangelands mention the dominance of the same families in the most stations. It is also the case in the studies published by Korichi (2016), Maamri (2016), Rahmoune (2018), Benalia et al. (2018) and Bekai et al. (2019) in the same region.

\section{The biological types}

The abundance of the various species related to their biological type according to Raunkiaer (1934) is as follows: therophytes > hemicryptophytes > chamaephytes $>$ geophytes $>$ phanerophytes, with a clear predominance of therophytes (71 taxa, 56\%) and hemicryptophytes (fig. 3). 
Table 2. List of the inventoried taxa.

Tableau 2. List des taxons inventoriés.

\begin{tabular}{|c|c|c|c|}
\hline Taxa (Dobignard \&Chatelain, 2010-13) & Biological types & Chorological types & Locality \\
\hline \multicolumn{4}{|l|}{ Aizoaceae } \\
\hline Aizoanthemopsis hispanicum (L.) Klak & Th & Med & SI \\
\hline \multicolumn{4}{|l|}{ Amaranthaceae } \\
\hline Atriplex canescens (Pursh) Nutt. & $\mathrm{Ch}$ & $\mathrm{Wd}$ & SIII \\
\hline Blitum exsuccum C. Loscos & Th & Wd & SI,SII \\
\hline Caroxylon vermiculatum (L.) Akhani \& Roalson & $\mathrm{Ch}$ & Wd & SI,SII \\
\hline Hammada schmittiana (Pomel) Botsch. & $\mathrm{Ch}$ & Sah & SI,SII \\
\hline Hammada scoparia (Pomel) Iljin & $\mathrm{Ch}$ & Sah & SI \\
\hline Noaea mucronata (Forssk.) Asch. \& Schweinf. & $\mathrm{Ch}$ & Wd & SI,SII,SIII \\
\hline \multicolumn{4}{|l|}{ Anacardiaceae } \\
\hline Pistacia atlantica Desf. & $\mathrm{Ph}$ & End (North Africa) & SI \\
\hline \multicolumn{4}{|l|}{ Apiaceae } \\
\hline Eryngium ilicifolium Lam. & Th & Med & SII \\
\hline Stoibrax pomelianum (Maire) B. L. Burtt & $\mathrm{Th}$ & End (Algeria-Morocco) & SIV \\
\hline Thapsia garganica $L$. & $\mathrm{Hc}$ & Med & SI,SII \\
\hline \multicolumn{4}{|l|}{ Apocinaceae } \\
\hline Nerium oleander $L$. & $\mathrm{Ph}$ & Med & SIII \\
\hline \multicolumn{4}{|l|}{ Asparagaceae } \\
\hline Muscari comosum (L.) Mill. & $\mathrm{Ge}$ & Med & SI,SII \\
\hline \multicolumn{4}{|l|}{ Asteraceae } \\
\hline $\begin{array}{l}\text { Anacyclus clavatus (Desf.). } \\
\text { Anacyclus monanthos subsp. cyrtolepidioides (Pomel) }\end{array}$ & Th & $\mathrm{Wd}$ & SI,SII,SIII,SIV \\
\hline Humphries & $\mathrm{Th}$ & End (North Africa) & SI,SIII \\
\hline Andryala integrifolia $L$. & Th & Med & SIV \\
\hline Artemisia campestris $L$. & $\mathrm{Ch}$ & Nor & SI,SII,SIII,SIV \\
\hline Artemisia herba-alba Asso & $\mathrm{Ch}$ & Med & SI,SII,SIII \\
\hline Atractylis caespitosa Desf. & $\mathrm{Hc}$ & Med & SI,SII \\
\hline Atractylis cancellata $L$. & $\mathrm{Th}$ & Med & SI \\
\hline Atractylis serratuloides Sieber ex Cass. & $\mathrm{Ch}$ & Sah & SI,SII,SIII \\
\hline Bombycilaena discolor (Pers.) M. Laínz & $\mathrm{Th}$ & $\mathrm{Wd}$ & SI,SII \\
\hline Calendula arvensis (Vaill.) L. & Th & Med & SI,SII,SIII,SIV \\
\hline Carduus spachianus Durieu & Th & Med & SI,SII \\
\hline Carthamus eriocephalus (Boiss.) Greuter & $\mathrm{Th}$ & Sah & SI \\
\hline Carthamus lanatus L. & $\mathrm{Th}$ & Wd & SI,SII,SIII,SIV \\
\hline Carthamus rhaponticoides (Pomel) Greuter & Th & End (Algeria-Morocco) & SIV \\
\hline Centaurea furfuracea Coss. \& Durieu & $\mathrm{Th}$ & Med & SI \\
\hline Centaurea maroccana BaIl & $\mathrm{Th}$ & Med & SI,SII,SIII \\
\hline Centaurea oranensis Greuter \& M. V. Agab. & $\mathrm{Hc}$ & End (Algeria-Morocco) & SI,SII,SIII,SIV \\
\hline Centaurea sicula $L$. & Th & Med & SI,SII, SIV \\
\hline Echinops spinosissimus Turra & $\mathrm{Hc}$ & Sah & SI,SII \\
\hline Erigeron trilobus (Decne.) Boiss. & $\mathrm{Th}$ & Med & SIII \\
\hline Filago crocidion (Pomel) Chrtek \& Holub & Th & End (Algeria-Morocco) & SI,SII,SIII \\
\hline Koelpinia linearis Pallas. & $\mathrm{Th}$ & Wd & SI,SII,SIII,SIV \\
\hline Launaea fragilis (Asso) Pau & $\mathrm{Th}$ & Wd & SI,SII \\
\hline Launaea mucronata (Forssk.) Muschl. subsp. mucronata & Th & Sah & SI,SII \\
\hline Launaea nudicaulis (L.) Hook. $f$. & Th & Wd & SII \\
\hline Onopordum acaulon $L$. & $\mathrm{Hc}$ & Med & SI,SII,SIII \\
\hline
\end{tabular}


Onopordum espinae Coss. ex Bonnet

Pallenis hierichuntica (Michon) Greuter

Pallenis spinosa (L.) Cass.

Picris asplenioides subsp. saharae (Coss. \& Kralik)

Dobignard

Reichardia tingitana (L.) Roth

Scolymus hispanicus $L$.

Scorzonera undulata Vahl

Senecio gallicus Vill.

Xeranthemum inapertum (L.) Mill

Boraginaceae

Echium humile subsp. pycnanthum (Pomel) Greuter \& Burdet Th

Lappula patula (Lehm.) Gürke

Brassicaceae

Brassica fruticulosa Cirillo

Clypeola cyclodontea Delile

Clypeola jonthlaspi subsp. microcarpa (Moris) Arcang.

Diplotaxis harra (Forssk.) Boiss.

Enarthrocarpus clavatus Delile ex Godr.

Eruca vesicaria (L.) Cav.

Maresia nana (DC.) Batt.

Matthiola fruticulosa (Loefl. ex L.) Maire

Matthiola longipetala (Vent.) DC.

Muricaria prostrata (Desf.) Desv.

Pseuderucaria clavata (Boiss. \& Reut.) O. E. Schulz.

\section{Caprifoliaceae}

Lomelosia crenata (Cirillo) Greuter \& Burdet

\section{Caryophyllaceae}

Herniaria cinerea $D C$.

Paronychia argentea Lam.

Silene secundiflora Otth

Telephium imperati L. subsp. imperati

\section{Cistaceae}

Helianthemum cinereum (Cav.) Pers.

Helianthemum helianthemoides (Desf.) Grosser

Helianthemum ruficomum (Viv.) Spreng.

\section{Cucurbitaceae}

Citrullus colocynthis (L.) Schrad.

\section{Euphorbiaceae}

Euphorbia falcata $L$.

\section{Fabaceae}

Argyrolobium uniflorum (Decne.) Jaub. \& Spach

Astragalus crenatus Schult.

Astragalus gombo Bunge

Astragalus reinii BaIl.

Coronilla scorpioides (L.) W.D.J. Koch

Hippocrepis multisiliquosa L.

Lathyrus clymenum L.

Lotus ornithopodioides L.

Medicago littoralis Loisel.

Medicago minima (L.) L.

\section{$\mathrm{Hc}$}

Th

$\mathrm{Ch}$

Th

$\mathrm{Th}$

$\mathrm{Hc}$

Ge

Th

Th

$\mathrm{Hc}$

$\mathrm{Hc}$

Th

Th

Th

Th

Th

$\mathrm{Ch}$

Th

Th

Th

Th

Th

$\mathrm{Hc}$

Th

$\mathrm{Hc}$

$\mathrm{Ch}$

$\mathrm{Ch}$

$\mathrm{Ch}$

$\mathrm{Hc}$

Th

$\mathrm{Hc}$

Th

$\mathrm{Hc}$

$\mathrm{Hc}$

Th

Th

Th

Th

Th

Th
Th
Med

Sah

Wd

End (North Africa)

Med

Med

Med

Med

Wd

Sah

$\mathrm{Wd}$

Med

Med

$\mathrm{Wd}$

Wd

End (North Africa)

Med

Wd

Med

Wd

End (North Africa)

Sah

Sah

Nor

Med

Med

Med

Wd

End (North Africa)

Med

Wd

Wd

Sah

Sah

Sah

End (Algeria-Morocco)

Med

Med

Med

Med

Med

$\mathrm{Wd}$
SI,SIII

SI

SI,SII,SIII

SI

SI,SII,SIII

SI,SII,SIII

SI,SII,SIII

SI,SII,SIII

SIII

SI,SII,SIII

SI,SII,SIII

SI,SII

SIV

SIV

SII

SI,SII

SI,SII

SI,SII,SIII,SIV

SI,SII,SIII

SIV

SI,SII

SI,SII,SIII

SIII

SI,SII,SIII,SIV

SI,SII,SIII,SIV

SI,SII,SIII,SIV

SIII

SI,SII,SIII

SIV

SI,SII

SIV

SIII

SII

SI,SII

SIII

SI,SII,SIII,SIV

SI,SII,SIII

SI

SI

SI,SII

SI,SII

SI,SII,SIII 
Onobrychis alba (Waldst. \& Kit.) Desv.

Ononis serrata Forssk.

Retama raetam (Forssk.) Webb

\section{Geraniaceae}

Erodium crassifolium (Forssk.) L'Hér.

Hyacynthaceae

Dipcadi serotinum (L.) Medik.

\section{Iridaceae}

Moraea sisyrinchium (L.) Ker Gawl.

Ajuga iva (L.) Schreb.

Maropsis deserti (de Noé) Pomel

Salvia verbenaca $L$.

Teucrium polium $L$.

Thymus algeriensis Boiss. \& Reut.

\section{Malvaceae}

Malva aegyptia $L$.

Malva parviflora $L$.

\section{Nitrariaceae}

Peganum harmala L.

\section{Orobanchaceae}

Cistanche lutea (Desf.) Hoffmanns. \& Link

\section{Papaveraceae}

Glaucium corniculatum (L.) Rudolph

Papaver hybridum $L$.

\section{Pinaceae}

Pinus halepensis Mill.

\section{Plantaginaceae}

Kickxia aegyptiaca (L.) Nábelek

Plantago albicans $L$.

Plantago ciliata Desf.

Plantago ovata Forssk.

\section{Poaceae}

Aegilops peregrina (Hack.) Eig

Anisantha rubens (L.) Nevski

Centropodia forsskalii (Vahl) Cope

Cynodon dactylon (L.) Pers.

Echinaria capitata (L.) Desf.

Hordeum murinum $L$.

Lygeum spartum $L$.

Macrochloa tenacissima (L.) Kunth

Poa bulbosa L. subsp. bulbosa

Rostraria cristata (L.) Tzvelev

Schismus barbatus (Loefl. ex L.) Thell.

Stipa parviflora Desf.

Stipagrostis obtusa (Delile) Nees

Stipagrostis plumosa (L.) Munro ex T. Anderson

Stipagrostis pungens (Desf.) De Winter subsp. pungens

Ranunculaceae

Adonis aestivalis $L$
$\mathrm{Hc}$

$\mathrm{Hc}$

$\mathrm{Ph}$

Th

$\mathrm{Ge}$

$\mathrm{Ge}$

Th

$\mathrm{Hc}$

$\mathrm{Hc}$

$\mathrm{Hc}$

$\mathrm{Ch}$

Th

Th

$\mathrm{Ch}$

Ge

Th

Th

$\mathrm{Ph}$

Th

$\mathrm{Hc}$

Th

Th

Th

Th

Th

Ge

Th

Th

Ge

$\mathrm{Hc}$

Th

Th

Th

$\mathrm{Hc}$

$\mathrm{Hc}$

$\mathrm{Hc}$

$\mathrm{Hc}$

Th
Nor

Med

Wd

Med

Wd

Nor

Med

Sah

Wd

Wd

End (North Africa)

Wd

Wd

Wd

End (North Africa)

Med

Med

Med

Sah

Med

Wd

Med

Med

Nor

Sah

Wd

Wd

Nor

Med

Med

Nor

Wd

$\mathrm{Wd}$

Med

Wd

Wd

Wd

Nor
SIV

SIV

SIII

SIII

SI,SII

SII,SIV

SI,SII,SIII

SI,SII,SIII,SIV

SIII

SI,SII

SI,SII,SIII

SIV

SI,SII,SIII

SI,SII,SIII

SI,SII,SIII,SIV

SIII

SI,SIV

SIV

SI

SI,SII,SIII,SIV

SI,SII,SIII

SI,SII,SIII

SII

SII,SIII,SIV

SI

SI,SII,SIII,SIV

SI,SII,SIII

SI,SII,SIII,SIV

SI,SII,SIII

SI,SIII

SIV

SI,SII

SI,SII

SI,SII,SIII

SIII

SI

SIII

\section{Resedaceae}




\begin{tabular}{|c|c|c|c|}
\hline Reseda alba L. subsp. alba & Th & Nor & SI,SIV \\
\hline Reseda decursiva Forssk. & $\mathrm{Hc}$ & Med & SI,SII,SIII \\
\hline Reseda lutea L. subsp. lutea & Th & Nor & SI,SII \\
\hline \multicolumn{4}{|l|}{ Rhamnaceae } \\
\hline Ziziphus lotus (L.) Lam. & $\mathrm{Ph}$ & Med & SI,SII,SIII \\
\hline \multicolumn{4}{|l|}{ Scrophulariaceae } \\
\hline Scrophularia canina $L$. & Th & Med & SIII \\
\hline \multicolumn{4}{|l|}{ Tamaricaceae } \\
\hline Tamarix gallica $L$. & $\mathrm{Ph}$ & $\mathrm{Wd}$ & SIII \\
\hline \multicolumn{4}{|l|}{ Thymelaceae } \\
\hline Thymelaea microphylla Coss. \& Durieu ex Meisn. & $\mathrm{Ch}$ & End (North Africa) & SI \\
\hline \multicolumn{4}{|l|}{ Zygophyllaceae } \\
\hline Tribulus terrestris $L$. & Th & $\mathrm{Wd}$ & SI \\
\hline
\end{tabular}

Wd: wide distributed; End: endemic; Sah: Saharian; Nor: Nordic; Med: Mediterranean; Th: therophytes; Ch: chamaephytes; Ph: phanerophytes; Ge: geophytes; Hc: hemicryptophytes.

Wd: large distribution; End: endémique; Sah: saharienne; Nor: nordique; Med: Méditerranéen; Th: thérophytes; Ch: chaméhytes; Ph: phanérophytes; Ge: géophytes; Hc: hemicryptophytes.

Indeed, the dominance of therophytes characterizes the arid and semi-arid regions (Aidoud, 1984; Miara et al., 2016). Several authors (Daget, 1980; Barbero et al., 1990; Aidoud, 1984) underline the relationship between the high rate of therophytes and the increasing gradient of aridity in the Algerian steppe areas. The phenomenon of therophytisation observed in the present study is probably related to

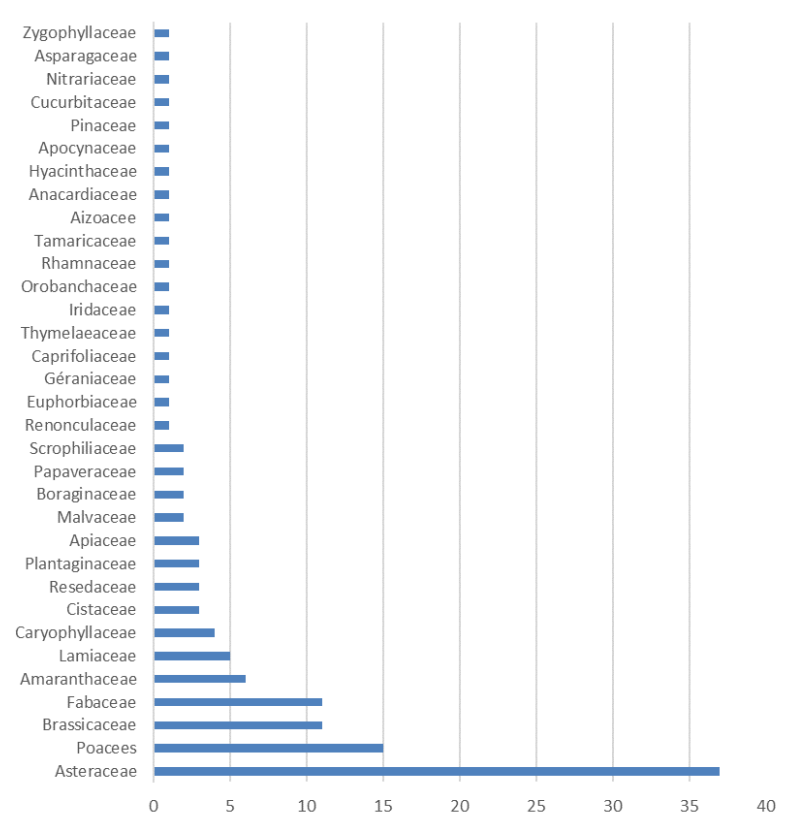

Number of taxa

Figure 2. The most represented families (number of taxa).

Figure 2. Les familles les plus représentées (nombre de taxons).

the arduous climatic conditions but also to the anthropogenic actions (Benabadji \& Bouazza, 2002; Benaradji et al., 2009; Hachemi et al., 2012). The high number of therophytes taxa represented in our list indicate some undergoing degradation of the local vegetation like in the Mediterranean region (Miara et al., 2016).

Hemicryptophytes are classified in second position of contribution with 27 taxa (21\%). The prevalence of hemicryptophytes can be explained by the degradation of the ecological conditions generally related to the climate and the anthropic action (Ozenda, 1977).

The other chorological types (chamaephytes, geophytes, phanerophytes) are moderately or weakly represented with 16,7 and 6 species respectively. Indeed, Kadi-Hanifi (2003) reported that the number of the phanerophytes, hémicryptophytes and geophytes declined with the aridity and openness of the environment.

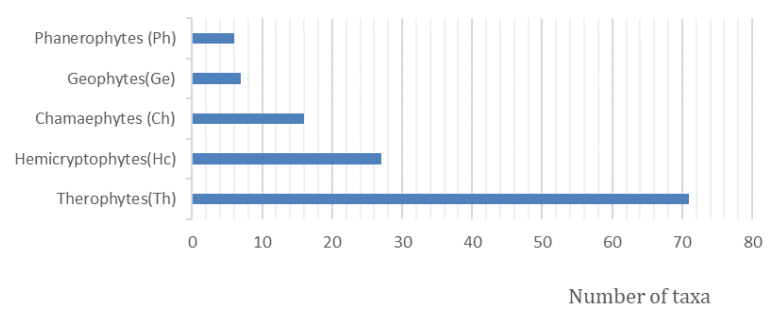

Figure 3. Biological types (number of taxa).

Figure 3. Types biologiques (nombre de taxons).

The rates of the perturbation index $(\mathrm{PI})$ in the four stations of study vary between $59 \%$ and $81 \%$. This confirms the presence of the phenomenon of Therophytization in these regions by the dominance of Therophytes annual species more or less needing water resources, trophic and the opening areas (Regagba, 2012). This also indicate the adaptation of these species to the effect of the anthropic actions (Grime,1977; Barbero et al.,1989a,1989b). The Therophytisation is the ultimate stage of degradation of the ecosystems with the dominance of the sub- 
nitrophiles species related to the overgrazing (Hachemi et al., 2002).

\section{Chorological types}

The chorological spectrum of our studied areas is generally marked by the prevalence of the Mediterranean element (48 taxa, 35\%). This reflects the global and logical affinity of our flora to the Mediterranean region that is generally appropriate to the climate which characterizes this area (Le Houerou, 1995; Quézel, 1983).

The wide distribution taxa come in second position with 38 taxa (28\%). The abundance of these species is generally related to the phenomenon of Therophytization of the Mediterranean flora induced by the action of several ecological and anthropogenic factors (Miara et al., 2016). The Nordic taxa occupies the third position with a total number of 19 taxa (14\%). This number can also be explained by the remote geographical location of northern Europe.

The Saharian element comes in fourth position with 17 taxa (13\%). The presence of a significant number of these taxa in these environments is explained by the geographic situation of the steppe areas bordering the desert (Aidoud, 1983).

Finally, the endemic type is represented with 14 taxa $(10 \%)$. These taxa belongs to Algerian-Moroccan (5 taxa) and North African elements (9 taxa). The number of endemic species reported in this study is quite low compared to the endemic taxon richness of these regions (Bekai et al., 2019). Indeed, an important reduction of the rates of endemic taxa in the steppe area was observed by the previous studies (Kadi-Hanifi, 2003; Abdelmoumen \& Zoheir, 2015; Nacère et al., 2016). In the Mediterranean region, these endemic taxa, even when they occur as Therophytes, are very fragile and vulnerable to anthropogenic disturbances (Quézel and Médail, 2003).

Thus, all the endemic species cited for the region in the flora of Quézel and Santa (1962-63) were not found in particular: Erodium hymenodes, Echium suffruticosum, Celsia battandieri, Bellium rotundifolium, Atractylis polycephala, A. phaeolepis. This may indicate local extinctions which are the result of a trivialization of the local flora by annual therophyte sub- nitrophiles taxa with greater ecological valence.

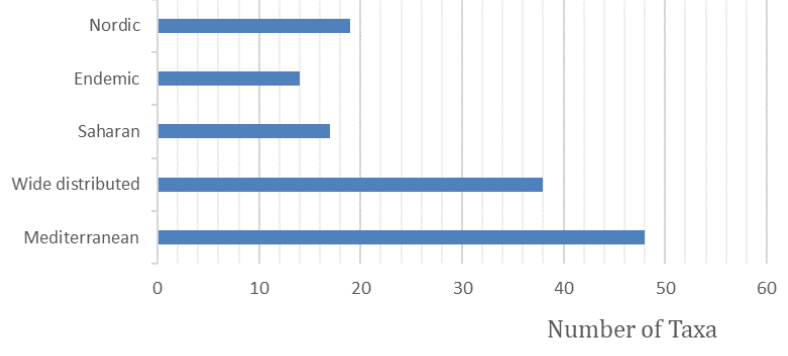

Figure 4. Chorological types (number of taxa).

Figure 4. Types chorologiques (nombre de taxons).

\section{Conclusion}

The results obtained show an interesting richness of the local flora (127 taxa, which is mainly dominated by therophyte taxa of low ecological and heritage value. It also turns out that the phenomenon of therophytization observed in this region has contributed to a certain "trivialization" of the regional flora which normally is quite specific and rich with strict endemic taxa. This is confirmed by the chorological analysis showing the absence of all endemic plants (including strict endemics) reported in this region in the past. In addition, the presence of a good number of other endemics of North Africa relatively preserves the floristic originality of this region. Finally, we insist on the necessity and the urgency to protect these natural spaces containing a rich and original biodiversity.

\section{Conflicts of interest}

The authors declare no conflict of interest throughout this research and writing process.

\section{References}

Abdelguerfi, A. \& Ramdane, M.S.A. (2003). Evaluation des besoins en matière de renforcement des capacités nécessaires à la conservation et l'utilisation durable de la biodiversité importante pour l'agriculture. Projet ALG/97/G31. Plan d'Action et Stratégie Nationale sur la Biodiversité. Tome XI, 230 p.

Abdelmoumen, S. \& Zoheir, M. (2015). Evaluation of Plant Diversity in the Steppes of White Wormwood of the Region of Saida (Western Algeria). Open Journal of Ecology, 5 (10): 491500. https://DOI: 10.4236/oje.2015.510040.

Aidoud, A. (1983). Contribution à L'étude des écosystèmes steppiques du Sud Oranais. U.S.T.H.B, Alger, 232p.

Aidoud, F. (1984). Contribution à la connaissance des groupements à sparte (Lygeum spartum L.) des hauts plateaux sud-oranais. Etude phytoécologique et syntaxonomique. Thése doct 3éme cycle, univ, Sci. Technol. H boumediéne, Alger, 256 p.+ ann.

Barbero, M., Bonin, G., Loisel, R. \& Quezel, P. (1989a). Sclerophyllous Quercus forests of the Mediterranean area: Ecological and ethological significance. Bielefelder. Okol. Beitr, 4:1-23. http://www.herbmedit.org/bocconea/13-011.pdf.

Barbero, M., Quezel, P., Loisel, R. (1989b). Disturbances and fires in the Mediterranean region. Int. Estud. Pyrenaicos. Jaca, 12: 194-215.

Barbero, M., Quezel, P. \& Loisel, R. (1990). Les apports de la phytoécologie dans l'interprétation des changements et perturbations induits par l'homme sur les écosystèmes forestiers méditerranéens. Forêt méditerranéenne, XII (3): 194-215.

http://www.foretmediterraneenne.org/upload/bibli o/FORET_MED_1990_3_194.pdf. 
Bekai, F., Kadik, L. \& Nedjimi, B. (2019). Effects of deferring grazing on the floristic diversity of Stipa tenacissima $\mathrm{L}$. rangelands in central Algerian steppe. Afr. J. Ecol, 00:1-8. https://doi.org/10.1111/aje.12614

Benabadji, N., Benmansour, D. \& Bouazza, M. (2007). La flore des monts d'Ain Fezza dans l'ouest Algérien, biodiversité et dynamique. Sciences \& Technologie. C. Biotechnologies, 26: 47-59.

Benabadji, N. \& Bouazza M. (2002).Contribution à l'étude du cortège floristique de la steppe au sud d'El Aricha (Oranie, Algérie). Sciences \& Technologie. C. Biotechnologies, 1: 11-19. http://revue.umc.edu.dz/index.php/c/article/view/ $1849 / 1969$.

Benalia, Y., Mostefa, T., Benzian, A., Elhadi, B., Mounir, G., Saoussane, K. \& Brahim., G. (2018). Therapeutic use of spontaneous medicinal flora from an extreme environment (dune cordon) in Djelfa region, Algeria. Journal of Pharmacy \& Pharmacognosy Research, 6 (5), 358-373.

Benaradj, A. (2009). Mise en défens et remontée biologique des parcours steppiques dans la région de Naâma: dissémination et multiplication de quelques espèces steppiques. Magistère thesis, Fac. Sci. Nat. et de la Vie, Univ. Mascara, 229p.

Braun-Banquet, J. (1951). Pflanzen soziologie. Grund zuge der Vegetation Kunde. Ed. 2. Springer, Vienne, Autriche. 227p. DOI https://doi.org/10.1007/978-3-7091-8110-2_1.

Cherfaoui, T. (2017). Etude de la Croissance et de l'accroissement du pin d'Alep dans la forêt Senalba Gharbi (Djelfa). Cas de la Série 13. Magister thesis. University of Tlemcen, 58p.

Daget, P. (1980). Sur les types biologiques botaniques en tant que stratégie adaptative (cas des thérophytes). In: Barbault, R., Blandin, P. \& Meyer, J. A. (eds), Recherches d'écologie théorique, les stratégies adaptatives. Maloine, Paris: 89-114.

Djaballah, F. \& Chehma, A. (2008). Effet de deux méthodes d'aménagement "mise en défens et plantation" sur les caractéristiques floristiques et nutritives des parcours steppiques de la région de Djelfa. Magistére thesis, University of Ouargla, 98p. http://hdl.handle.net/123456789/463

Djebaili, S. (1978). Recherches phytosociologiques et phytoécologiques sur la végétation des hautes plaines Steppiques et de l'Atlas Saharien. Doctorate thesis. University of Montpellier, $229 \mathrm{p}$.

Djebaili, S. (1984). Algerian steppe, phytosociology and ecology. O.P.U. Algiers. 171p.

Dobignard, A. \& Chatelain, C. (2010-2013). Index synonymique de la Flore d'Afrique du Nord, V: 15. Genève.

Fennane, M. \& Ibn Tattou, M. (2012). Statistiques et commentaires sur l'inventaire actuel de la flore vasculaire du Maroc. Bulletin de I'Institut Scientifique, Rabat, section Sciences de la Vie, 2012, n³4 (1): 1-9.

Gounot, M. (1969). Méthode d'étude quantitative de la végétation. Masson, Paris, 308p.
Grime, J.P. (1977). Evidence for the existence of three primary strategies in plants and its relevance to ecological and evolutionary theory. The American Naturalist, 111 (982): 11691194.

https://doi.org/10.1086/283244.

Hachemi, N., Hasnaoui, O., Benmehdi, I., Medjati, N. \& Bouazza, M. (2012). Contribution à l'étude de la thérophytisation des matorrals des versants sud des monts de Tlemcen (Algérie occidentale). Mediterranea, 23: 158-180. DOI: 10.14198/MDTRRA2012.23.06

Halem, M. (1997). La steppe Algérienne: causes de la désertification et propositions pour un développement durable. MSc dissertation, University Sidi Bel Abes, Algeria.

Kadi-Hanifi, H. (2003). Diversité biologique et phytogéographique des formations à Stipa tenacissima L. de l'Algérie. Science et changements planétaires/Sécheresse, 14 (3): 169-179.

Kazi-Tani, C., Le Bourgeois, T. \& Munoz, F. (2010). Contribution à l'étude des communautés d'adventices des cultures du secteur phytogéographique Oranais (nord-ouest algérien): aspects botanique, agronomique et phyto-écologique. AFPP.

Korichi, A. (2016). Etude floristique et ethnobotanique de Chouchet Tobdji (forêt de Sénalba Chergui) Région de Djelfa. Magister thesis. Univ Djelfa, 78 .

Le Houerou, H. N. (1969). La Végétation de la Tunisie steppique : structure, écologie, sociologie, répartition, évolution, utilisation, biomasse (productivité, avec références aux végétations analogues d'Algérie, de Libye et du Maroc). Annales de I'Institut National de la Recherche Agronomique de Tunisie, 42 (5): 1- $643+$ Annexes.

Le Houerou, H.N. (1995). Bioclimatologie et biogéographie des steppes arides du nord de l'Afrique. Diversité biologique, développement durable et désertification. Option méditerranéenne. Ser. B: recherches et études, $369 \mathrm{p}$.

Loisel, R. \& Gamila, H. (1993). Traduction des effets de débroussaillement sur les écosystèmes forestiers et pré-forestiers par indice de perturbation. Ann. Soc. Sci. Nat. Arch. Toulon: 123-132.

Maamri, F. (2016). Les espèces pastorales et fourragères originaires de la steppe Algérienne: distribution, diversité et voie d'utilisation. ENSA Alger, 220p.

Médail, F. \& Quézel, P. (1997). Hot-spots analysis for conservation of plant biodiversity in the Mediterranean basin. Ann. Missouri Bot. Gard, 84: $112-127$

Miara, MD., Ait Hammou M, Hadjadj Aoul S, DahmaniW, Negadi M, Rebbas K, Bounar R. \& Smaili T. (2016). Note sur les thérophytes dans les monts de Tiaret (massif de Guezoul- Algérie occidentale). Revue Ecologie - Environnement, 12: 17-24. 
Miara, MD., Ait Hammou, M., Dahmani, W., Negadi, M. \& Djellaoui A. (2018a). Nouvelles données sur la flore endémique du sous-secteur de l'Atlas tellien Oranais "O3" (Algérie occidentale). Acta Botanica Malacitana, 43: 63-69. https://doi.org/10.24310/abm.v43i0.4453

Miara, MD., Bendif, H., Ait Hammou, M. \& TeixidorToneu, I. (2018b). Ethnobotanical survey of medicinal plants used by nomadic peoples in the Algerian steppe. Journal of Ethnopharmacology, 219: 248-256. https://doi.org/10.1016/j.jep.2018.03.011

Mittermeier, R.A., Robles Gil P., Hoffmann M., Pilgrim J., Brooks T., Mittermeier C.G., Lamoreux J., Da Fonseca, G.A.B. (2004). Hotspots revisited: Earth's biologically richest and most endangered terrestrial ecoregions, Preface by Peter A. Seligmann, Forewordby Harrison Ford. Cemex, Conservation International, Agrupacion Sierra Madre, Monterrey, Mexico, p. 392.

Myers, N. (1988). Threatened biotas: Hotspots in tropical forests. Environmentalist, 8, 178-208.

Myers, N. (1990). The biodiversity challenge: Expandedhotspots analysis. Environmentalist, 10: 243-256.

Nedjraoui, D. \& Bédrani, S. (2008). La désertification dans les steppes algériennes: causes, impacts et actions de lutte. Vertigo, V: 8, $\mathrm{n}^{\circ} 1$. http://vertigo.revues.org/index448.html.

Ozenda, P. (1977). Flore du Sahara (Deuxième édition revue et complétée). CNRS, Paris, 622p. Quézel, P \&. Santa, S. (1962,1963). Nouvelle flore
d'Algérie et des régions désertiques méridionales. Tomes I et II, $1170 \mathrm{p}$.

Quézel, P. (1983). Flore et végétation actuelles de l'Afrique du nord, leur signification en fonction de l'origine, de Involution et des migrations des flores et structures de végétation passées. Bothalia, 14 (3/4) : 411-416. DOI: 10.4102/abc.v14i3/4.1186.

Quézel, P \&. Médail, F. (2003). Ecologie et biogéographie des forêts du bassin méditerranéen. Elsevier, Paris. 571 p.

Rahmoune, A. (2018). Ecologie et analyse floristique de la végétation et de la flore de la forêt de Sahary Guebli (réserve de chasse) Wilaya de Djelfa. Master thesis. University of Batna, 135p.

Regagba, Z. (2012). Dynamique des populations végétales halophytes dans la région sud-est de Tlemcen. Aspects phytoécologiques et cartographiques. Doctorate thesis. Univeristy of Tlemcen, 179p.

Vela, E \& Benhouhou, S. (2007). Evaluation d'un nouveau point chaud de biodiversité végétale dans le bassin méditerranéen (Afrique du nord). C.R. Biologies, 330: 589-605.

Zehraoui, R. \& Kadik, L. (2016). Résultats préliminaires de l'étude de l'impact des reboisements du barrage vert sur la biodiversité floristique cas de la région de Djelfa (Algérie). Séminaire International «Biodiversité et Changements Globaux» Djelfa, 11p. https://www.researchgate.net/scientificcontributio ns/2132032359_Zehraoui_Rabia 